\author{
ks. Vincenzo de Giregorio
}

Pontificio Istituto di Musica Sacra

\title{
Kościót, sztuka i muzyka: doświadczenie poszukiwań i odnajdywania zawsze nowych horyzontów ${ }^{1}$
}

\section{Prceludium}

Proszę pozwolić, że się przedstawię. Urodziłem się na małej wyspie na południu Włoch. Małej, ale słynnej - Capri. Na wyspie tej funkcjonują dwie wspólnoty obywatelskie, dwie gminy - Capri i Anacapri - a w każdej z nich znajduje się po jednej parafii. Anacapri jest najmniejszą miejscowością i gminą na wyspie, z parafią pod wezwaniem Świętej Zofii, co świadczy o wpływie, jaki na początku pierwszego tysiąclecia na południu Włoch miał wschodni Konstantynopol.

W roku 1956 miałem 10 lat i - jak wielu moich rówieśników - pełniłem posługę ministranta. Proboszcz, który będąc jeszcze w seminarium, nauczył się amatorsko gry na organach, uczył nas czytać po łacinie i śpiewać epistołę podczas mszy świętej śpiewanej w niedzielę. Emilia Gubitosi, muzyczka i nauczycielka w neapolitańskim konserwatorium, założycielka orkiestry Scarlatti, bardzo znanej we Włoszech, usłyszała, jak śpiewam, i poprosiła mego ojca, by pozwolił mi jechać z nią do Neapolu uczyć się muzyki. Ojciec się zgodził. Zaważyło to na całym moim życiu. Dzięki muzyce w kościele poznałem „wielką muzykę”. Później studiowałem na uniwersytecie Urbanianum w Rzymie i tam również pobierałem naukę gry na organach i kompozycji w Papieskim Instytucie Muzyki Sakralnej.

W swojej karierze nauczyciela gry na organach w konserwatorium miałem również okazję pełnić funkcję dyrektora tej instytucji. Poznałem wówczas bliżej wielu młodych studentów muzyki. Przeważająca większość z nich z muzyką po raz pierwszy zetknęła się albo w kościele, albo w lokalnym zespole muzycznym, w którym grali ich ojcowie czy dziadkowie. Ciekawy i godny przypomnienia jest zatem fakt, że wielu młodych poznaje muzykę i zbliża się do niej dzięki Kościołowi i dzięki działalności muzycznej lokalnych zespołów.

1 Wystąpienie na konferencji w Krakowie, 22 listopada 2017 roku. 
To nie przypadek, że w wielu krajach szkoła muzyczna nazywa się właśnie „konserwatorium”. Sam przez 10 lat byłem dyrektorem konserwatorium w Neapolu. Archiwa podają, że właśnie w tym mieście, w pierwszej połowie XVI wieku, powstała szkoła muzyczna nazwana Konserwatorium. Po włosku czasownik conservare oznacza „zachować, utrzymywać przy życiu”. Jak wiemy, w historii naszych narodów dzieła miłosierdzia były praktycznym przełożeniem Ewangelii na życie. W Neapolu dzieła miłosierdzia prowadzone były przez bractwa nazywane też kongregacjami świeckich. Konserwatoria muzyczne były zaś instytutami świeckich konfraterni w Kościele zakładanymi jako placówki opiekuńcze, mające na celu „zachowanie, utrzymanie przy życiu” dzieci - pierwszych ofiar wojen, głodu czy epidemii dżumy.

Na bazie moich wczesnych doświadczeń sam muszę przyznać, że w moim przypadku, jak i w przypadku wielu młodych ludzi, spotkanie z muzyką dokonało się dzięki Kościołowi. Z kolei na podstawie wiedzy historycznej można stwierdzić, że idea szkół muzycznych wyrosła z działalności charytatywnej Kościoła i w Kościele.

Bez wątpienia idea szkoły muzycznej - takiej, jaką jest w kulturze zachodniej - powstała zatem w Kościele. Z jakiego powodu? Myślę, że odpowiedź na to pytanie tkwi w pragnieniu Kościoła, który nie chciał pozostawić sztuki i muzyki improwizacji, ale z zaangażowaniem i mocą pragnął kultywować i wspierać poszukiwanie ich wysokiej jakości. Nie wiem, czy w języku polskim istnieje analogiczne do włoskiego powiedzenie - we Włoszech, aby wyrazić znakomitą jakość, mówimy „di prim’ ordine” („pierwszorzędnie” - przyp. tłum.).

Wyrażenie to, użyte przez Simone Weil w tekście, który teraz zacytuję, pomaga mi przedstawić temat tego wystąpienia i podzielić się nim z Wami. Simone Weil pisze mianowicie w swoich „Zeszytach”:

We wszystkim, co budzi w nas czyste i autentyczne uczucie piękna, jest jakby rodzaj wcielenia Boga: zatem cała pi erw szo orzęd n a sztuka w istocie jest religijną, będąc świadectwem przemawiającym za Wcieleniem. Melodia gregoriańska daje takie świadectwo, jak śmierć męczennika.

Simone Weil stawia także problem przymiotnika „sakralny” w odniesieniu do muzyki. Wiemy skądinąd, że do dziś temat muzyki sakralnej wywołuje dyskusje i polemiki. Wiele osób, używając przymiotnika „sakralny”, rozdziela muzykę przeznaczoną dla liturgii i inspirowaną wiarą, pomyślaną i skomponowaną dla chrześcijańskiej duchowości, od „innej muzyki” - „niesakralnej”.

Nie ulega jednak wątpliwości, że istnieje przede wszystkim „muzyka”, która - owszem - w niektórych sytuacjach wymaga przymiotnika ,sakralny” dla zdefiniowania swojej funkcji, historii, przeznaczenia. Muzyka ta, jak stwierdza Simone 
Weil, musi być „pierwszorzędna”, „di prim’ ordine” - możliwie najlepszej jakości. We wszystkich ludzkich sposobach wyrazu, a przede wszystkim w sztuce, to jakością udaje się wyrazić to, co niewyrażalne, odesłać wierzących do tego, co transcendentne - do Boga. Męczennik daje świadectwo aż do przelania krwi, że wierzy w Boga, któremu powierzył całego siebie. Sztuka, dla tworzących ją i dla korzystających z niej, jest świadectwem wiary w wielkość naszego kruchego człowieczeństwa, kiedy temu człowieczeństwu udaje się wytworzyć coś „pierwszorzędnego”. Taką sztukę przeszywa promień Bożego Ducha. Dlatego właśnie muzyka jest „boska”.

[To wam oznajmiamy], co było od początku, cośmy usłyszeli o Słowie życia, co ujrzeliśmy własnymi oczami, na co patrzyliśmy i czego dotykały nasze ręce - bo życie objawiło się (1 J 1, 1-2).

Autor Pierwszego Listu świętego Jana znajdującego się w Nowym Testamencie przypomina energię pochodzącą $\mathrm{z}$ wiary w doświadczenie zmysłów, aby wskazać wszystkie formy wyrazu, które mają ujście w sztuce i którym Tradycja i nauczanie Kościoła przyznały nadzwyczajną głębię teologiczną: widzieć, kontemplować, dotykać, oznajmiać. Te cztery czasowniki wyrażają całą dynamikę sztuki i muzyki w życiu społecznym i duchowym. W obrębie wielkich religii ten, ściśle mówiąc, teologiczny aspekt sztuki, jest osobliwością właściwą dla chrześcijańskiej wizji relacji Bóg-człowiek. Ekumeniczny Sobór Nicejski II, który przywołał prawo obecności sztuki chrześcijańskiej i jej wielką wartość teologiczną w Kościele, odbija się echem w słowach Jana Pawła II, który dla upamiętnienia właśnie tamtego soboru, pisał:

Sztuka Kościoła musi dążyć do tego, by przemawiać językiem Wcielenia i wyrażać, za pomocą materialnych elementów, Tego, który raczył zamieszkać w materii i poprzez materię dokonać naszego zbawienia²

Musimy następnie dodać refleksję na temat innego jeszcze aspektu obecności muzyki w chrześcijańskiej kulturze: w specyficznym obszarze muzyki wszystkie religijne formy wyrazu w historii tworzyły formy muzyczne, mniej lub bardziej złożone i opracowane, ale w tradycji chrześcijańskiej, od zarania jej dziejów, muzyka zajmowała uprzywilejowane miejsce, ponieważ nie była celem samym w sobie, wyłącznie jako artystyczna forma wyrazu, ale ponieważ była narzędziem komunikowania Słowa Bożego zwracającego się do Kościoła oraz słowem Kościoła zwracającego się do Boga.

2 Jan Paweł II, list apost. Duodecimum Saeculum, 4 grudnia 1987, przyp. tłum. 
Z pewnością jedną z ważnych cech charakterystycznych obecności chrześcijaństwa w historii ludzkości jest to, że zajmowało się ono zarówno głoszeniem Słowa Bożego, jak i sakramentami, do których to posług przygotowywano w procesie odpowiedniej formacji, ukierunkowanej na „profesjonalizm”. Jednym z najbardziej owocnych pod tym względem wydarzeń, które począwszy od XVI wieku na trwałe wniosły wkład w nowożytne chrześcijaństwo, był Sobór Trydencki, który zadecydował o powstaniu seminariów dla formacji kleru. W gruncie rzeczy nie chodziło tylko o nadanie wagi należytej formacji duchowej, lecz także o pragnienie i zagwarantowanie formacji dla wszystkich prezbiterów, zwłaszcza tych, którzy nie należeli do zakonów; zagwarantowanie skutecznej formacji kulturalnej i intelektualnej, a zatem „profesjonalizmu”. Skuteczność głoszenia Słowa związana została przez samego Chrystusa z posługą. Nie można zaprzeczyć, że jedną z podstawowych przyczyn dynamiczności i żywotności Kościoła w historii ludzkości jest obecność specyficznych posług w służbie przekazywania wiary i celebracji wiary w liturgii. Kościół nigdy nie pozwolił, aby posługi te były owocem improwizacji. Przeciwnie, przymioty umysłu i serca były warunkami dopuszczenia do danej posługi. Ze względu na to, jak ważna była muzyka zarówno w życiu liturgicznym sensu stricto, jak i w przejawach pobożności i uczuć chrześcijańskich, we wszystkich formach artystycznego wyrazu Kościół formował przygotowane i kompetentne osoby według kryterium mówiącego o tym, że wychowanie umysłu i serca jest podstawowym elementem każdej struktury społecznej w historii.

Czy można mówić o jakimś „stylu” Kościoła, z jakim troszczy się on ogólnie o sztukę, a w szczególności o muzykę? Myślę, że tak. Ów „styl” mogą wyznaczać dwie, podstawowe drogi:

a) historyczna (spojrzenie w przeszłość), jako ciągłość i wierność doświadczeniom przeszłości, a zatem jako wierność korzeniom;

b) misyjna, która zawsze jest zaangażowaniem w budowanie dzisiaj warunków przyszłego rozwoju.

Kościół w Jerozolimie wyśpiewywał swoją wiarę w Jezusa, przyjmując z liturgii świątynnej styl śpiewania psalmów, hymnów, kantyków i aklamacji. Nie wiemy zbyt wiele na temat śpiewu pierwszych wspólnot, ale jesteśmy pewni, że w środowisku judeo-chrześcijańskim formy i gatunki muzyczne zaczerpnięte były z praktyki żydowskiej. Kiedy Ewangelię zaczęto głosić w regionach mających korzenie inne niż hebrajskie, które określamy po prostu jako „pogańskie”, zawsze pierwszym repertuarem i pierwszym sposobem wykonywania śpiewu w tych wspólnotach było to, co przejęto ze stylu żydowskiego. Jednak muzyka ludów, w których głoszono i celebrowano wiarę, od początku swoim stylem i językiem wpływała na śpiew liturgiczny.

My, którzy dzisiaj tu, w Krakowie, zastanawiamy się nad tym, stanowimy ostatnie ogniwo długiego łańcucha, który objął kraje i narody, głęboko odbijając 
się w ich kulturze poprzez sztukę. Moglibyśmy nawet stwierdzić, że wszystko to zdarzyło się w szczególnych, bardzo sprzyjających warunkach, właśnie w Kościele zachodnim. Te sprzyjające warunki możliwe były dzięki zdolności kon frontacji bez niszczenia. Była to również jedna z cech charakterystycznych „ł a ci ńsk ości”. Jednym z najbardziej skomplikowanych okresów życia naszego Kościoła (pozostawiam bez odpowiedzi pytanie, czy kiedykolwiek był jakiś „nieskomplikowany” okres) był czas końca zachodniego Imperium Rzymskiego, który miał doprowadzić do nowej konfiguracji sił politycznych, a który doprowadził do powstania Świętego Cesarstwa Rzymskiego. Bohaterem, który w owych trudnych latach stawiał czoła zaistniałej sytuacji i patrzył w przyszłość z doskonałą inteligencją, ale i zmysłem praktycznym codzienności, był papież Grzegorz Wielki, którego pontyfikat przypadł na lata 590-604.

Dobrze wiemy, że we wszystkich aspektach ludzkiej historii, zarówno tych kulturowych, jak i duchowych, gospodarczych i społecznych, nic nie dzieje się nagle. Dlatego należy pamiętać, że kiedy Grzegorz został wybrany na papieża, by wkrótce stać się bohaterem historii Kościoła, który rzutował na całą Europę, pewne wydarzenia, które przyczyniły się do utworzenia warunków dla przyszłego rozwoju sztuki i muzyki, były już faktem. Przypomnijmy pokrótce niektóre z nich:

a) wraz z pontyfikatem papieża Damazego I (366-384) zostaje ugruntowany autorytet biskupa Rzymu jako następcy Świętego Piotra, głowy Apostołów, w przedmiocie dyscypliny i liturgii;

b) papież Leon Wielki (440-461) umacnia prymat stolicy rzymskiej ponad cesarza Konstantynopola;

c) w VII wieku inwazja Longobardów wyznacza ostateczny koniec władzy cesarza Konstantynopola na Zachodzie;

d) Grzegorz Wielki przejmuje rządy cywilne w Rzymie, potwierdza władzę Rzymu nad biskupami Italii; utrzymuje relacje z innymi Kościołami Zachodu.

W roku 596 papież Grzegorz Wielki wysyła do Wielkiej Brytanii misję apostolską złożoną z 40 mnichów pod przewodnictwem Augustyna, który zostanie biskupem Canterbury - późniejszego świętego Augustyna z Canterbury. Zachowały się 2 listy, które papież Grzegorz I wysłał do świętego Augustyna z Canterbury. Drugi z nich jest odpowiedzią na pytanie postawione przez Augustyna: co zrobić ze zwyczajami religijnymi zastanymi u ludów, które misjonarz ewangelizuje? Zwalczać i niszczyć wszystko czy zachować?

Papież Grzegorz tak odpowiada świętemu Augustynowi z Canterbury:

Znasz, Bracie, zwyczaj Kościoła rzymskiego, w którym, jak dobrze pamiętasz, zostałeś wychowany. Ale uważam, że ty z troskliwością wybrać powinieneś to, co znajdziesz zarówno w Kościele rzymskim, jak i w Kościołach 
Galii i jakimkolwiek innym, co będzie mogło się podobać Bogu wszechmocnemu, wprowadzając i utrwalając w Kościele Anglików, który jeszcze jest młodym w wierze, najważniejsze zwyczaje, jakich się nauczysz od innych Kościołów... Dlatego wybieraj z każdego poszczególnego Kościoła praktyki prawe, pobożne, religijne i te składaj, jako zebrane w wiązkę, w umysłach Anglików, ażeby się stały zwyczajami...

Grzegorz Wielki był Rzymianinem, pochodził ze szlacheckiej rodziny. Otrzymał świetne wykształcenie prawnicze i administracyjne jeszcze przed formacją chrześcijańską i monastyczną. Jako Rzymianin rozumiał dobrze koncepcję ius gentium.

Łacińskie słowo ius pochodzi od indoeuropejskiego ious czy yewsche, czyli „zasada odpowiedniego działania, odpowiedź na wymagania”. Ius to projekt praktycznego i teoretycznego rozwiązania problemów wpisanych w unitarną wizję rzeczy. Grzegorz zatem, według rzymskiej zasady, która uznaje obecność ius gentium (prawa narodów) obok prawa typowo rzymskiego przyswoił idę̨ włączania.

Tak więc nowe narody przyjmowały chrzest. Wizygoci, chrześcijańscy arianie, którzy osiedlili się w Hiszpanii, przeszli na katolicyzm. Od czasu synodu w Toledo w 589 roku ścisły związek łączył Kościół z ich królestwem.

Katolickimi chrześcijanami stali się również Frankowie. Królowie Franków cieszyli się takimi prerogatywami jak cesarze rzymscy - w 511 roku Chlodwig zwołuje synod biskupów w Galii.

Biskupi starożytnych miast rzymskich oraz misjonarze pochodzenia celtyckiego (Irlandczycy i Szkoci) i anglosaskiego poświęcają się ewangelizacji pogan, arian i semiarian. Nieprzypadkowo pierwszy niemęczennik czczony w Kościele zachodnim to święty Marcin, biskup Tour (Francja) żyjący w IV wieku, a kanonizowany ze względu na swoje zaangażowanie nie tylko duszpasterskie, lecz także społeczne i kulturalne, w szczególności wśród ludności pozamiejskiej.

Tam, gdzie nie istniały miasta i wielkie ośrodki miejskie (Irlandia), ewangelizowali mnisi, tworząc nowe tradycje liturgiczne. W klasztorach śpiewano podczas modlitw, wraz z miejscową ludnością wykonywano prace na roli, studiowano i praktykowano medycynę, niesiono pomoc ubogim i rozpowszechniano kulturę antyczną.

W całym tym wielkim ruchu politycznym, militarnym, kulturalnym i religijnym prymat w dyscyplinie i liturgii wiódł Kościół rzymski, który stworzył warunki dla powstania zachodniej sztuki i muzyki, co legło u podstaw artystyczno-kulturowego zjawiska asymilacji. Żadna religia w historii świata nie przyczyniła się do tak wielkiego, szerokiego i zróżnicowanego rozwoju sztuki jak Kościół zachodni. Dokonało się to właśnie w ramach poszukiwania profesjonalizmu, również w sztuce i muzyce. 
Aby mieć solidne podstawy i przetrwać w czasie, profesjonalizm potrzebuje miejsc formacji. Kościół zachodni zaangażował się w formację muzyczną z taką energią i mając do dyspozycji takie osobistości, które w historii nie mają sobie równych. Alberto Basso w dziele poświęconym historii muzyki tak oto pisze o tej działalności dydaktycznej:

Powolną, acz postępującą naprzód działalnością (całkowicie przeciwną do biernej i statycznej działalności Kościołów wschodnich), Kościół zachodni - który w swym najwyższym wyrazie jest Kościołem rzymsko-katolickim - potrafił obdarzyć naszą kulturę śpiewem, tak zwanym gregoriańskim, samym w sobie doskonałym i kompletnym, zdolnością „funkcjonalną”, dzięki której przetrwał kryzys czasów. Bardzo nam odległy, a przecież tak bliski i obecny w historii naszej muzyki, która bez niego nie tylko oczywiście byłaby inna, ale byłaby wręcz nie do pomyślenia (...). Powstały jako modlitwa, jako uniesienie, jako ozdoba kultu, jako Boży dar, ów śpiew wykracza poza granice wiary. Przez przynajmniej siedem, osiem wieków był on jedyną muzyką, o jakiej mamy świadectwa, muzyką nieznającą barier ani ideologicznych, ani doktrynalnych, która rozprzestrzeniła się wszędzie, zwyciężając gusta i przyzwyczajenia lokalne ${ }^{3}$.

Te „7, 8 wieków”, kiedy to śpiew kościelny był jedynym żywym świadectwem muzycznym w zachodnim świecie, to nie stulecia bezruchu, nie apatyczne i statyczne utrzymywanie ustalonego raz na zawsze repertuaru muzycznego. Były to wieki „szkoły”. Setki lat, podczas których śpiew Kościoła rzymskiego konfrontował się z formami śpiewu stosowanymi wśród ludów całej Europy. Z takiej syntezy wykiełkował śpiew gregoriański, który z kolei stał się polem do eksperymentów i poszukiwań, na podstawie którego opracowano najdoskonalszy i najbardziej złożony system muzyczny, jaki ludzkość kiedykolwiek utworzyła: polifonię. Śpiew monodyczny, następnie polifonia, potem gra na organach, a wreszcie gra na innych instrumentach... Kościół akceptuje i włącza w liturgię wszystkie te formy artystyczne oraz kolejne instrumenty. To szkoły katedralne i klasztorne zachęcają do poszukiwań i same prowadzą eksperymenty rodzące się z intuicji, z najprostszych elementów śpiewu, by wreszcie opracować reguły, gramatykę i syntezę muzyczną harmonii, kontrapunktu i wielkich form takich jak fuga. $\mathrm{Z}$ tego systemu, dziś klasyfikowanego jako harmonia i kontrapunkt, wezmą początek orkiestra, chóralność, muzyka symfoniczno-chóralna, melodramat (aż do harmonii, które jeszcze dzisiaj są podstawą tak zwanej

\footnotetext{
3 A. Basso, Storia della musica dalle origini al XIX secolo, Torino 2004, przyp. tłum.
} 
muzyki „lekkiej”) i dzieła kompozytorów uznanych za największych w historii muzyki. Ten repertuar, jedyny taki przykład na świecie, wykonywany jest na wszystkich kontynentach, jeszcze dzisiaj budząc entuzjazm i syntonię. „Pasja” wzbudzana przez tę muzykę to nie zamiłowanie do jakiegoś języka muzyki - pop, folkowej czy etnicznej - ale do jej zdolności komunikacji między ludźmi pochodzącymi z różnych kultur. Właśnie dzięki „szkole muzycznej”, rozwiniętej i działającej w Kościele, dziś możemy odróżnić muzykę etniczną, popową i folkową od muzyki poważnej.

Najczęściej mówi się i pisze o działalności Kościoła i jego zasługach w dziedzinie nauk humanistycznych i ścisłych, a dużo rzadziej o jego działalności na polu muzycznym. Jednak to, co przypomnieliśmy powyżej w odniesieniu do wierności historii, pokazuje, że ewolucja praktyki muzycznej na Zachodzie jest owocem ciągłej i systematycznej działalności Kościoła właśnie w obrębie muzyki. Można by stwierdzić, że nauczanie muzyki w Kościele nie jest często podkreślane, bo jest działalnością zwyczajną, codzienną, tak jak zwyczajne i codzienne jest życie liturgiczne, które nigdy się nie zatrzymuje. Ponadto sam fakt, że sztuka muzyczna jest nienamacalna i nieuchwytna, że może być utrwalona tylko w pamięci, a nie w materii (jak dzieje się w przypadku malarstwa, rzeźby i architektury), czyni mniej oczywistą jej obecność w historii Kościoła. Niemniej jednak muzyki i śpiewu w Kościele uczono od zawsze.

Powód, dla którego w Kościele prowadzono nauczanie muzyczne, tkwi w samej naturze misji Kościoła: głoszeniu Boga, który stał się człowiekiem w Jezusie Chrystusie. Podążając za kryterium, według którego to, co święte, nie może być komunikowane zwyczajnymi środkami. Święte słowa dyktowane przez Boga czy święte słowa wypowiadane przez Kościół do Boga nie mogą być banalne. Potrzebna jest muzyka, dlatego to, co Kościół m ó wi, jest śpiewane. Kościół, który ewangelizuje, wyśpi ew u je swoją wiarę. Taka była misja, jaką postawił przed sobą Kościół w czasach Grzegorza Wielkiego, kiedy Kościół zachodni zaczęło zajmować miejsce Imperium Rzymskiego w całej Europie. Taka też była misja Kościoła, kiedy począwszy od XVI wieku, tworzył religijny repertuar muzyczny ludów Ameryki Łacińskiej, Afryki i Azji. Wtedy to otwarły się 2 muzyczne drogi: droga ściśle muzyczna, po łacinie, i droga ludowej pobożności, w językach używanych przez prosty lud.

W praktyce misja Kościoła w dziedzinie muzyki wyraża się przede wszystkim w życiu liturgicznym. Na Zachodzie wyłączne użycie języka łacińskiego jako języka liturgii aż do drugiej połowy XX wieku miało 3 podstawowe konsekwencje:

a) postępujące oddalanie się ludzi od aktywnego uczestnictwa w wydarzeniu liturgicznym. Trzeba jednak zauważyć, że miało to również pozytywną stronę: we wszystkich strefach językowych obok śpiewu ściśle liturgicznego narodził się religijny śpiew pobożności ludowej, który przeszedł nadzwyczajny rozkwit, stanowiąc fundamentalne karty historii muzyki poszczególnych narodów; 
b) rozwijająca się specjalizacja śpiewu liturgicznego, która obejmowała z wieku na wiek coraz to nowe języki i nowe formy muzycznego wyrazu, jako owoc eksperymentów i poszukiwań realizowanych w szkołach, w przykościelnych kapelach muzycznych i chórach liturgicznych. Tego typu działalność prowadzona w Kościele pozostawała zawsze w aktywnej, wzajemnej relacji wymiany z muzyką świecką;

c) wzrastająca liczba powstających profesjonalnych formacji muzycznych, zarówno wokalnych, jak i instrumentalnych, a co za tym szło - utrwalenie się reguł praktyki muzycznej (i ogólnie artystycznej) na poziomie najwyższym z możliwych.

Misja ta zrealizowana została także w formacyjnych strukturach szkolnych i uniwersyteckich. Nauczanie muzyki i jej wykonywanie stały się integralnymi częściami ratio studiorum, organizacji studiów. Każdy rok szkolny i akademicki kończył się „akademią”, której podstawę stanowiła muzyka. „Wierność misji” w epoce nowożytnej doprowadziła do tego, co można określić jako „wiosnę muzyki kościelnej” - popchnęła do studiów i ponownego odkrycia oryginalnego śpiewu gregoriańskiego oraz praktycznego powrotu do polifonii liturgicznej w drugiej połowie XIX wieku. Nie przez przypadek owa „wiosna” zasłużyła na specjalną uwagę papieża mającego za sobą doświadczenie proboszcza i biskupa - święty Pius X wydał bowiem dokument poświęcony tej tematyce ${ }^{4}$. Pius X pierwszym papieżem czasów nowożytnych, który miał doświadczenie życia parafialnego i diecezjalnego i który znał zwyczajne życie liturgiczne ludu z własnej praktyki.

Muzyka dla liturgii i muzyka w liturgii musiały przejść głębokie zmiany. Ta prawdziwa rewolucja jeszcze lepiej jest widoczna, jeśli weźmie się pod uwagę fakt, że repertuar muzyczny w języku łacińskim liczy sobie ponad 1500 lat, a repertuar współczesny ma zaledwie 50 lat. Jak więc dzisiaj ma wyglądać muzyka przeznaczona dla liturgii, jakie mogą być dzisiejsze cechy muzycznej praktyki, aby była ona wierna historii, wierna misji i aby funkcjonowała w przyszłości?

Proponuję definicję powstałą na bazie doświadczenia wszystkich muzyków kościelnych: „wykonywanie muzyki w Kościele jest doświadczeniem wiary, promieniującą estetyczną radością, która porusza najgłębsze zakamarki egzystencji”.

Estetyczna radość, która towarzyszy tej muzyce, to nie estetyka sentymentalizmu czy powierzchownych emocji. Muzyka liturgiczna ma charakter „modlitewny”, wyrażający się przede wszystkim w byciu wspólnotą, rodziną Bożą, Kościołem. Bycie Kościołem w trakcie modlitwy ma z kolei tę konsekwencję, że modlitwa zamienia się w miłosierną miłość i staje się dla świata żywym świadectwem prawdy, wolności, sprawiedliwości i pokoju.

4 Pius X, list motu proprio Inter pastoralis officii sollicitudines, 1903 - przyp. tłum. 
Muzyka, o której mowa na tej konferencji w Krakowie, nie jest „powierzchowną i anonimową sztuką dźwięków" (jak się ją określa). To ona (z harmoniami, które znamy, z usystematyzowanymi normami rytmów, zgodnie z którymi walc, swing, tango czy koncert rockowy są tym, czym są) jest „naszą” muzyką, tą, dzięki której istnieje cały nasz świat muzyczny, od ścieżek dźwiękowych filmów i seriali telewizyjnych po operę, koncerty gwiazd na stadionach, po jazz i po cały pejzaż dźwięków, jaki otacza nas nawet nocą. Ta muzyka zrodziła się tam, gdzie my dzisiaj gramy i śpiewamy - w kościele.

U początków naszej muzyki - „naszej”, czyli świata zachodniego - która rządzi się najbardziej skomplikowanymi zasadami, jakie kiedykolwiek opracowano na tej planecie, z jej orkiestrą instrumentów dętych, smyczkowych i perkusyjnych, z jej ogromnym repertuarem sięgającym początków „współczesnego” świata, czyli I połowy wieku XVII, gdy Monteverdi komponował Nieszpory najświętszej Maryi Panny i Orfeusza, po kompozycje Chopina, Strawińskiego i Szostakowicza, stali kantor i muzycy opactw i szkół katedralnych.

To ta muzyka stała się muzyką Mozarta, Brahmsa, Verdiego i Pucciniego, a wraz z nimi wyrazem tradycji nie tylko ludowej, ale również uczonej - chociaż ludowość również znalazła w niej swoje miejsce. Trzeba bowiem pamiętać, że aż do założenia pierwszych uniwersytetów jedynym miejscem utrzymującym kulturę, miejscem studiów i tworzenia kultury były klasztory i ich biblioteki oraz archiwa katedralne.

Należy wystrzegać się fałszywej opinii, wedle której muzyka kościelna była spontaniczna i inspirowana, nie zaś oparta na poważnych studiach. Gdyby rzeczywiście tak było, my jako Kościół nie bylibyśmy twórcami największej artystycznej epopei (nie tylko muzycznej), jaką ludzkość kiedykolwiek posiadała.

$\mathrm{Z}$ tego punktu widzenia, stanowiącego nie opinię, a fakt historyczny, zrozumiałe jest, jak dalekie od historii liturgii, Kościoła i muzyki są repertuary tych ruchów, które sprowadziły śpiew liturgiczny do banalnych języków muzycznych, które już nawet nie są ludowe, ale po prostu niekompetentne.

\section{Postludium}

Rozpocząłem swoje wystąpienie od przypomnienia pierwszych wersetów hymnu wprowadzającego w pierwszym rozdziale do Ewangelii świętego Jana: „Słowo stało się Ciałem...”. Na zakończenie dodam do słów Ewangelii rozwinięcie: „Słowo stało się Ciałem, a Kościół wcielił je sztuką i muzyką". Musimy jednak dodać jeszcze inny aspekt tego wcielenia.

Mówiłem o konserwatoriach muzycznych, powstałych z pragnienia Kościoła, aby pomagać, zapewniając opiekę i szkołę muzyczną dzieciom padającym ofiarą 
materialnej i duchowej biedy. Jestem księdzem diecezji neapolitańskiej, a w Neapolu kościoły są szczególnie bogate w sztukę i piękno. Od 17 lat jestem prałatem przełożonym królewskiej kaplicy Skarbu Świętego Januarego. To duży kościół posiadający niezwykłe dzieła sztuki. W kaplicy Świętego Januarego znajdują się aż 54 srebrne figury świętych współpatronów miasta naturalnej wielkości. Razem z wszystkimi innymi ozdobami ołtarza stanowią one największą na świecie srebrną kolekcję dzieł zgrupowanych w jednym miejscu. Są tu dzieła sztuki tworzące galerię obrazów i rzeźb z XVII wieku, unikalną w skali świata. Znajdziemy tu także nadzwyczajne ozdobne przedmioty kultu Świętego Patrona: mitra biskupia na figurze-relikwiarzu Świętego z 1305 roku, wykonana z pozłacanego srebra, wysadzana 4000 kamieniami szlachetnymi - 2222 diamentamiami, 168 rubinami i 196 szmaragdami, a ponadto kielichy, puszki na komunikanty i monstrancje o unikatowej wartości.

Dzisiaj moglibyśmy powiedzieć, że tworzenie takich przedmiotów to przesada i marnotrawstwo pieniędzy. I to prawda. Ale kiedy wszystkie te rzeczy powstawały, miasto otwierało również konserwatoria muzyczne dla biednych dzieci; istniejący do dzisiaj szpital dla pielgrzymów - obcokrajowców, którzy zapadali na choroby; szpital dla nieuleczalnie chorych niemających nadziei na wyzdrowienie, a którymi opiekowano się aż do śmierci; Bank Neapolitański ufundowany przez Świętego Kajetana, służący pomocą ofiarom lichwy; Dom Zwiastowania Najświętszej Marii Panny dla dzieci, których nie miał kto wychowywać i które w domy stawały się „dziećmi Madonny”; istniejący po dziś dzień budynek Pio Monte della Misericordia dla ubogich opuszczonych oraz dziesiątki bractw dla wszystkich kategorii ludzi, by towarzyszyć im i opiekować się nimi za życia i przy śmierci. A zatem było to miasto zorganizowane w imię wiary, piękna i miłosiernej miłości. Podobnie działo się w innych miastach Europy.

Gdzie ludzie mogli zobaczyć w tamtych czasach dzieła sztuki? Tylko w kościołach. W Kościele, który otaczał się sztuką i muzyką, aby dać przestrzeń i czas dla Słowa Bożego i liturgii i który wraz ze sztuką i muzyką dał taką samą przestrzeń dla dzieł miłosierdzia. Było to bowiem ciąłe poszukiwanie dobra i piękna.

Wiemy, że każde działanie ludzkie zanurzone jest w pełni w przestrzeni i czasie. Architektura, malarstwo, rzeźba zajmują miejsce. Muzyka zajmuje czas. Słowo Boże rodzi się z ciszy odwiecznego Ojca, przyjmuje czas i wchodzi w przestrzeń ludzką. Podstawą historyczną muzyki w liturgii jest skoncentrowanie się na Słowie Bożym. Słowo Boże karmi codzienną historię - słuchamy go i odpowiadamy naszymi słowami w liturgii. Słuchanie, mówienie i śpiewanie potrzebują przestrzeni i czasu.

Dla swej liturgii i muzyki Kościół stworzył fizyczną przestrzeń architektoniczną, w której można je przeżywać i słuchać. Architektura odpowiada przede wszystkim na potrzebę fizyczną: ma sprawić, by przesłanie dotarło do szerokie- 
go grona słuchaczy. Przesłania tego nie można wykrzykiwać. Aby zostało właściwie zrozumiane - jest wyśpiewywane. Jednak architektura jest także przestrzenią, w której czas odgrywa swą rolę. Głoszone Słowo Boże oraz odpowiedź wiary stają się śpiewem. Muzyka jest zaś jedyną sztuką, która absolutnie potrzebuje czasu.

Przestrzeń i czas zorganizowane przez Kościół odpowiadają dokładnie na potrzeby ludzkiej dynamiki: potrzebę komunii i pokonania chaosu.

Muzyka kościelna dostrzega wartość etosu, który Grecy przypisywali sztuce za pomocą apolińskich cech: równowagi, harmonii i duchowego spokoju.

Dzisiaj my jako spadkobiercy tej niezwykłej historii wiary i sztuki nosimy na sobie odpowiedzialność za to, by nadal utrzymywać i przekazywać następnym pokoleniom ideę równowagi między koncepcją sztuki jako virtus cujusdam celestis influxus (moc, jakby boski, niebiański wpływ - dar Boga) a vehementia assiduae exercitationis (intensywne, długie ćwiczenie i trening - owoc ludzkiej inteligencji).

W erze globalizacji i informatyki, gdy burzone są wszystkie schematy obowiązujące w przeszłości, jesteśmy wezwani, jako odpowiedzialni za liturgię i muzykę kościelną, by nadal podejmować trud studiów i nauczania. Sztuka i muzyka są owocem ingenium et opus (inteligencji, wysiłku, zaangażowania) i dopełniają się $\mathrm{w}$ opus consummatum et effectum (kompletnym i efektywnym dziele sztuki). Nasze chóry, nasi muzycy i wychowawcy są żywym świadectwem tej nadzwyczajnej, na wskroś chrześcijańskiej historii: Słowo stało się Ciałem, a Kościół wciela je w historii ludzi miłością i pięknem.

\section{Abstrakt}

Kościót, sztuka i muzyka: doświadczenie poszukiwań i odnajdywania zawsze nowych horyzontów ${ }^{5}$

Na kanwie osobistych doświadczeń z muzyką, począwszy od wczesnej młodości przez lata studiów muzycznych, pełnienia różnych kierowniczych funkcji w instytucjach muzycznych, autor dochodzi do przekonania, że sama idea szkoły muzycznej zrodziła się w Kościele. Kościół zawsze nauczał muzyki i śpiewu. Muzyka liturgiczna zawsze była postrzegana jako „pierwszorzędna” („di prim’ordine”) i domagała się od jej wykonawców profesjonalizmu. Od zarania dziejów Kościoła była nie tylko formą artystycznego wyra-

5 Wystąpienie na konferencji w Krakowie, 22 listopada 2017 roku. 
zu i celem sama dla siebie, ale narzędziem komunikowania Słowa Bożego oraz słowem Kościoła zwracającego się do Boga. „Profesjonalizm” muzyki w Kościele potrzebuje jednak miejsc formacji i nauczania, aby móc przetrwać w czasie i mieć solidne podstawy do wytyczania kierunku dla przyszłości. Ten postulat nauczania muzyki ma swoje podstawy w samej naturze misji Kościoła, który ewangelizując, „wyśpiewuje” swoją wiarę. Autor proponuje swoją własną, powstałą także na bazie doświadczeń wielu muzyków, „definicję” muzyki kościelnej: „Wykonywanie muzyki w Kościele jest doświadczeniem wiary, oświeconej estetyczną radością, która porusza najgłębsze zakamarki duszy”. Z tak pojmowanej muzyki kościelnej rodzi się nasza odpowiedzialność za to, aby nadal utrzymywać i przekazać następnym pokoleniom ideę równowagi między koncepcją sztuki jako niebiańskiego daru Boga (virtus cujusdam caelestis influxus) a owocu ludzkiej inteligencji (vehementia assidue exercitationis). Sztuka i muzyka - według autora - są owocem (ingenium et opus) inteligencji, wysiłku i zaangażowania oraz dopełniają się w kompletnym i efektywnym dziele sztuki (opus cansummatum et effectum).

Stowa klucze: Kościół, Neapol, Rzym-Watykan, Papieski Instytut Muzyki Kościelnej, muzyka kościelna, szkoła muzyczna, sztuka muzyczna, formacja muzyczna, doświadczenie wiary

\section{Abstract}

Church, art and music: the experience of constant seeking and discovering new horizons

On the basis of his own experiences of music, starting with the early childhood, throughout the university studies, until holding various managerial positions at music institutions, the author reaches the final conclusion that the very idea of musical school was born in the Church. The Church has always taught music and singing. Liturgical music has invariably been viewed as "primordial” ("di prim'ordine”), requiring professional skills from its performers. It has not only been a form of artistic expression or the aim in itself, but an instrument of communicating the Gospel and the words directed by the Church to God since the dawn of her history. The "professionalism" of the music within the Church, however, calls for the places of formation and education, so as to endure in time and to lay the foundation for setting guidelines to follow. The above postulate of teaching music in the Church originates from the very mission of the latter which, through her evangelization, "sings out" her faith. The author proposes his own, based on the experi- 
ences of many musicians as well, "definition" of the Church music: "Performing music in Church is the experience of faith, enlightened with aesthetic joy which moves the deepest recesses of the soul". The Church music, understood in this way, evokes in us responsibility for preserving and passing down to next generations the idea of balance between the conception of art as the celestial gift of God (virtus cujusdam caelestis influxus) and the fruit of human intelligence (vehementia assidue exercitationis). Art and music - according to the author - are the fruits (ingenium et opus) of intelligence, efforts and commitment, and they compound with one another into a complete and final work of art (opus cansummatum et effectum).

Keywords: Church, Naples, Rome-Vatican, the Pontifical Institute of Sacred Music, sacred music, music school, the art of music, musical formation, the experience of faith

\section{Bibliografia}

Basso A., Storia della musica dalle origini al XIX secolo, Torino 2004.

Pius X, motu proprio Inter pastoralis officii sollicitudines, 1903. 